\title{
ENTRE A LUA E A RUA: UMA TOPOLOGIA SOCIAL DA CLANDESTINIDADE POLÍTICA NA CIDADE DO RIO DE JANEIRO, 1969-1973*
}

Henri Acselrad

\begin{abstract}
Fui me encontrar com Zé Roberto, no Leme [...] Ele segurou seu cachimbo suavemente, virou-se para mim e disse: - Vinha andando para esse encontro e um cara no ônibus me dizia que os sequestradores do embaixador americano eram as pessoas que ele mais admirava. Os sequestradores do embaixador americano e os cosmonautas. Depois disso, Zé Roberto me olhou bem nos olhos e perguntou: - não somos cosmonautas, somos? (F. Gabeira, 1988:49).
\end{abstract}

[...] fomos até um barzinho na rua da faculdade encontrar com outros companheiros que tentavam avaliar o momento histórico. Chegamos à conclusão que o movimento operário, apesar dos discursos políticos de primeiro de maio, dava-se apenas no plano econômico. [...] Resolvemos pegar um ônibus e ir até um lugar bem alto da cidade, onde podíamos avistar uma boa parte de São Paulo, para chorar a nossa decepção. Tivemos uma grande surpresa quando nos deparamos com alguns companheiros de outras organizações que tiveram a mesma ideia. Cumprimentamo-nos e, arrasados, lamentamos não viver ainda sob o socialismo (Y. Falcon, 2007:60).

Numa reportagem publicada no jornal espanhol El País, com o título de "El Rastro de la Dictadura - breve topografia de la clandestinidad", o jornalista escrevia:

Descrever uma topografia da clandestinidade na Madri da última fase do franquismo requer situar, no horizonte simbólico de seus protagonistas, ao norte, o ideal europeísta; a leste, o impulso revolucionário de cunho marxista, soviético ou chinês; a oeste, o liberalismo anglo-saxão; e ao sul, a referencia ética da classe trabalhadora, com o eixo Vallecas-Entrevías como emblema [...] No centro da cidade, aposentava-se o poder, com marcos como a Secretaria 
Geral do Movimento, a sede do partido único, na rua Alcalá, 44 [...] (R. Fraguas, El País, 9/8/2006).

A matéria em questão sugere que uma topografia simbólica situava a resistência à ditadura franquista num espaço de posições relativas. A luta clandestina pode, pois, configurar uma determinada espacialidade e, poderíamos acrescentar, uma topologia. Pois enquanto na citação acima, referente ao caso espanhol, a clandestinidade antifranquista é associada aos pontos cardeais da geopolítica europeia, ${ }^{1}$ no caso dos relatos da luta contra a ditadura 1964-1985 no Brasil, vemos ganhar destaque, no universo simbólico de seus protagonistas e analistas, antes de tudo, distâncias e altitudes. Assim é que a literatura sobre a resistência à ditadura que se instaurou no Brasil em 1964 ressalta sistematicamente a distância entre as pretensões revolucionárias das organizações de esquerda e as condições concretas - de desmobilização — de setores oprimidos da sociedade. Os personagens sociais em questão pareciam estar situados em planos distintos, justificando a colocação recorrente da pergunta: estariam os militantes, tal como cosmonautas, pairando acima da sociedade?

O episódio relatado por Yara Falcon, acima transcrito em epígrafe, sugere que, ao contrário do que correntemente se supõe, essa percepção da distância não estava ausente e era mesmo comum, já na época, a muitos dentre os próprios militantes. Ela exprimia com força, como o ilustra o episódio narrado, a expectativa que então compartilhavam de alcançar uma aproximação com a urbe: angustiados com os sinais de seu isolamento, ativistas da luta clandestina de diferentes grupos, coincidentemente, subiram ao ponto mais alto da cidade, procurando obter uma "visão" mais elucidativa do espaço social sobre o qual atuavam.

É dessa topologia das distâncias e altitudes que procuramos tratar no presente texto - não só das distâncias imediatamente políticas, objeto já de ampla literatura, mas das distâncias sociais e culturais que também estiveram presentes na experiência da luta clandestina no Brasil e que estão dialeticamente ligadas aos impasses daquela luta política. Para identificar a sociabilidade específica produzida na experiência da clandestinidade, procuramos observar de forma mais específica, no âmbito da cidade, lugar onde se desenvolveram com predominância as atividades de luta contra a ditadura, ${ }^{2}$ espaços sociais relativamente restritos e situações envolvendo um número reduzido de indivíduos.

Tal focalização se justifica na medida em que a existência clandestina implicava, conforme assinalaram Almeida e Weis (1998:327), uma "infiltração da privacidade pela política", posto que "nos regimes de força, os limites 
entre as dimensões pública e privada são mais imprecisos e movediços do que nas democracias" e "a resistência ao regime inevitavelmente arrasta a política para dentro da órbita privada", dado que parte ponderável da atividade política é trama clandestina que deve ser ocultada dos órgãos repressivos. Em acordo com esta perspectiva, vamos tentar nos aproximar daqueles âmbitos relativamente circunscritos em que a militância clandestina estabeleceu diferentes tipos de relação com os demais habitantes da cidade, relações estas sempre subordinadas à natureza das atividades políticas então desenvolvidas. Isto nos levará a tentar exercitar sobre nosso objeto o que Goffman chamou de uma "sociologia das circunstâncias", em que "a organização social é o tema central, mas a matéria organizada é feita de conjunções de pessoas e de interações temporárias que podem aí surgir". Tais interações constituem, por um lado, uma "entidade movente, necessariamente evanescente, criada pelas chegadas e suprimida pelas partidas", mas constituindo também "relações sintáticas que unem as ações das diferentes pessoas mutuamente em presença" (Goffman 1974:8) e que são, em nosso caso, fortemente condicionadas pelo contexto macropolítico do regime de exceção.

Aplicada à luta clandestina desenvolvida no Brasil na passagem dos anos 1960 aos anos 1970, tal sociologia pode somar esforços aos daqueles que buscaram entender o fenômeno da resistência à ditadura naquele período para além da discussão sobre as razões de sua derrota. É certo que se trata aqui de um esforço muito particular de produzir uma "sociologia histórica das circunstâncias", sem a possibilidade de recorrer à observação etnográfica das situações. Mas se a realização desta observação, por um lado, teria sido evidentemente problemática à época da ditadura, a busca, 40 anos depois, do esclarecimento de certos aspectos ainda poucos estudados da experiência histórica do período justifica um esforço, ainda que indireto, de reconstituição daquelas peculiares situações de interação. Pretendemos, assim, agregar aqui algum esclarecimento sobre elementos constitutivos da experiência daquela luta, abstendo-nos de tomar como ponto de partida o já conhecido resultado imediato desse processo, a saber, a destruição das organizações que o protagonizaram entre 1968 e $1973 .^{3}$

É comum apontar-se, nas investigações da microssociologia da vida cotidiana, a falta de enfoques que evidenciam as mudanças históricas que afetam a cotidianidade (Cárcamo 1993:194). Em nosso caso, tratamos, ao contrário, de considerar mudanças na vida cotidiana que tiveram sua origem numa crise das próprias estruturas macropolíticas do país. Assim é que, para esta discussão, a teatralização da vida cotidiana e a impressão que os indivíduos procuram oferecer aos demais nas relações interpessoais remetem a 
realidades sociais que ultrapassam os marcos da própria interação, levando a que possamos considerar a figura do militante clandestino como a de um personagem coletivo e histórico. Isto porque este personagem tanto emerge das contradições e da crise do Estado, como modifica as condições correntes da vida cotidiana da cidade.

Para a presente discussão, foram adotados os seguintes passos metodológicos:

a) foram identificadas na literatura testemunhal as referências a episódios que expressem, de algum modo, as relações dos clandestinos com a cidade, com vizinhanças de subúrbios onde, predominantemente, moraram e com co-habitantes de casas de cômodos em que se hospedaram; o recurso a este tipo de fonte explica-se pelo fato de que dela se procurou recolher elementos que sustentam a hipótese deste trabalho e que foram, até aqui, pouco explorados, dado que os estudos - notadamente históricos - desenvolvidos sobre a luta clandestina no período se haviam concentrado nas questões relativas às estratégias políticas das organizações de esquerda e às formas da ação repressiva que sobre estas se abateu;

b) foram selecionados informantes junto a redes de sociabilidade estabelecidas entre antigos militantes, identificando-se aqueles que estiveram na clandestinidade - desvinculados de sua identidade legal e de seus meios de origem — na cidade do Rio de Janeiro entre 1969 e 1973. Foram entrevistados, entre os anos de 2008 e 2011, 23 homens e 27 mulheres integrantes de 11 organizações diferentes, das quais duas abstiveram-se de ações armadas; dentre os 50 entrevistados, oito foram deslocados para a produção fabril;

c) com aqueles que se dispuseram a ser entrevistados, foram realizadas entrevistas semiabertas, de cerca de duas horas de duração, com roteiro incidente sobre suas relações com a cidade, as vizinhanças e os co-habitantes de casas de cômodos em cada local de moradia de que os informantes tinham lembrança;

d) foram identificados, nas falas, os episódios que descreviam a "objetividade" das relações com vizinhança e co-habitantes de casas de cômodos, deixando-se de lado a apreciação dos sujeitos a este respeito; buscou-se identificar elementos em comum na reconstrução das lembranças individuais dos entrevistados, considerando-se não se tratar, neste caso, da recuperação de uma memória já enquadrada por pontos de referência construídos por grupos ou instituições. A despeito da disponibilidade de livros testemunhais 
e filmes, com seus respectivos efeitos sobre a memória, levamos em conta que a dimensão coletiva e organizada dos discursos sobre a experiência da clandestinidade política no período estudado mostra-se fracamente constituída sob a forma do que Pollak havia designado de "fatos de memória" (Pollak 1989);

e) procedeu-se à interpretação microssociológica dos episódios narrados tendo por base os conceitos goffmanianos de "situação de interação", "consenso operacional", "expressões emitidas" e "expressões transmitidas". ${ }^{4}$ Nessas narrativas, procurou-se analisar a sequência de situações — supondo-as verossímeis - buscando-se deixar de lado as apreciações valorativas explícitas dos sujeitos da narração a respeito delas;

f) finalmente, procedeu-se à identificação, nas sequências de eventos narradas, das situações de interação similares - apresentando alguma regularidade - presentes tanto na literatura testemunhal como nas entrevistas, justificando as hipóteses apresentadas, mais adiante explicitadas, de "ajuste nos padrões de interação" e "encontro de culturas" — consideradas, ademais, as diferenças de "horizontes de expectativa" e de "campos de experiência" entre militantes e moradores - conceitos tomados de empréstimo de R. Koselleck ${ }^{5}$ - assim como o processo de (des)constituição de "arenas públicas" a partir dos trabalhos de D. Cefai;

g) uma complementação dos cenários de análise foi configurada com os relatos, aí sim, contendo descrições e apreciações sobre a cidade na ótica do militante clandestino, apreciações que não foram, entretanto, evocadas diretamente na análise das "situações de interação".

\section{Clandestinidade e cidade}

É sabido que após a edição do Ato Institucional número 5 (AI-5), em dezembro de 1968, com o endurecimento do regime, estreitou-se o espaço para mobilizações de massa, intensificando-se as ações armadas desencadeadas por grupos organizados. As condições da vida clandestina nas cidades tornaram-se mais estritas, devendo as organizações de resistência à ditadura aliar, em sua logística, o aluguel de imóveis ao aluguel de quartos em casas de cômodos ou mesmo de vagas em quartos. Ao lado das ações políticas desencadeadas nas cidades, podemos presumir que a própria vida corrente dos militantes clandestinos alterou de várias maneiras o cotidiano do ur- 
bano. Se supusermos, hipoteticamente, que cerca de 300 pessoas tenham estado na clandestinidade política na cidade do Rio de Janeiro entre 1969 e $1973^{6}$ — período em que se concentraram as ações contrárias ao regime — morando em apartamentos, quartos ou vagas alugadas, por razões de segurança situados notadamente nos subúrbios da cidade, ${ }^{7}$ e em rotação relativamente rápida, dadas as condições de risco e instabilidade da luta política à época, ${ }^{8}$ teria sido significativo o encontro da militância clandestina com a população da cidade, seja em relações de vizinhança, co-habitação ou da simples circulação cotidiana.

Como os então clandestinos perceberam a reação dos citadinos à presença de suas figuras urbanas particulares que, provenientes em grande parte das classes médias, ${ }^{9}$ a despeito dos esforços para não se diferenciarem nos meios suburbanos onde passaram a viver, guardavam por vezes traços de comportamento incomuns para os moradores daquelas áreas?

Pelas estatísticas do projeto Brasil Nunca Mais, 62,7\% das pessoas atingidas pela repressão e envolvidas em processos políticos tinham curso universitário incompleto ou completo, sendo 64,5\% com idade inferior a 30 anos. ${ }^{10}$ Ora, na população economicamente ativa, segundo o Censo Demográfico de 1970, os diplomados e estudantes universitários perfaziam apenas 3,9\%, enquanto a população com menos de 30 anos representava apenas 27,6\% da população total (Reis Filho 1989:170). Portanto, se considerarmos que a proporção de mais escolarizados era acentuadamente mais baixa nas áreas de circulação do contingente de militantes clandestinos nas cidades, este grupo destacava-se por ser muito mais jovem e escolarizado que a média da população daquelas áreas. Faz sentido supor, consequentemente, que as interações sociais próprias à situação de clandestinidade, além de fazerem parte, como sabido, do encontro entre sujeitos com distintos horizontes de expectativa política, fizeram parte também, em alguma medida, de uma experiência de encontro intercultural de grupos sociais de origens diferentes.

O encontro entre sujeitos sociais com referenciais culturais distintos, associado a contextos de militância política contestatária, tem longa história, desde o deslocamento dos populistas russos — os chamados narodniks para o campo, ao final do século XIX, à transferência de intelectuais indianos para áreas tribais na segunda metade do século XX, ou ao établissement de estudantes maoístas em fábricas francesas nos anos 1960 (Linhart 1994; Neveu 2008). A experiência de luta clandestina no Brasil nos anos 1970 incluiu também certo número de casos de deslocamento de estudantes para o trabalho fabril, ${ }^{11}$ assim como de co-habitação entre quadros oriundos das classes médias e militantes ou simpatizantes de origem popular. 
Mas o que nos interessa aqui é aproximar as situações de interação em que habitantes de subúrbios reagiam à presença de jovens relativamente mais intelectualizados, não necessariamente "deslocados para a produção", mas habitando bairros onde tradicionalmente residia população de indivíduos, em termos relativos, de renda mais baixa e menos escolarizados. Pelo viés desse "encontro de culturas" relativamente distintas, pretendemos vislumbrar, ainda que de forma indireta, ${ }^{12}$ facetas pouco conhecidas do modo como a população das cidades pareceu se posicionar diante dos que combatiam o regime de exceção.

Cabe a pergunta: será que na chamada "zona cinzenta", situada entre o combate à ditadura e o apoio explícito a ela, não se teria configurado também uma "zona urbana cinzenta", onde, ainda que sob a operação do estímulo à delação e do dispositivo da tortura destinados a imobilizar pelo medo "a sociedade governada" (Vinãr \& Viñar 1992:60), ${ }^{13}$ ter-se-ia verificado, em certas circunstâncias, em relação aos militantes, fora dos circuitos da resistência, manifestações de complacência, empatia ou cumplicidade?

Numa primeira abordagem, salta de fato aos olhos a disposição recíproca ao isolamento: os clandestinos evitando maiores contatos com a população urbana, deslocados como estavam de seus meios de origem - "autoexilados" e em estado de permanente vigilância e suspeição — enquanto a população parecia preferir não ver para não ser envolvida numa trama de perigos. A condição urbana do clandestino remete ao que Benjamin, lendo Allan Poe, chama de dialética da flânerie: de um lado, o homem que se sente olhado por tudo e por todos, como um verdadeiro suspeito; de outro, o homem que dificilmente pode ser encontrado, o escondido. ${ }^{14}$ Para os militantes, a ruptura da rede de relações pessoais "legais", estabelecendo limites à sua sociabilidade, implicava, de fato, um isolamento. Por outro lado, a constituição de outra rede de relações - baseada nos laços de lealdade e solidariedade com os demais companheiros, por sua vez também não plenamente identificados promovia uma compartimentação, interna e externa, das organizações que reforçava o isolamento social (cf. Almeida \& Weis 1998:376, 384; Ferreira 1996:113, 114; Ridenti 1993:255).

Assim, para muitos, as atividades clandestinas pressupunham o segredo como forma de proteção (Simmel 2003[1996]:62) e, consequentemente, justificavam um movimento de autorreclusão. No entanto, para um número significativo de militantes e de situações, as relações com elementos externos às organizações aconteciam. Ou seja, numa observação mais aguda, podemos admitir que, a despeito do enorme retraimento da esfera pública, os clandestinos, de posse de suas novas identidades, teciam laços com moradores da cidade - vizinhos circunstanciais, passantes, personagens da 
rua, seja em seus locais altamente rotativos de habitação, seja em suas vias de circulação e articulação na cidade. Entre os sentimentos de "liberdade e solidão" (Ridenti 1993:250), entre "o medo e a exaltação", ${ }^{15}$ construíam relações sociais nas quais tendiam a mesclar traços da identidade assumida com traços de sua identidade original, operando uma espécie de antropologia espontânea, analisando em permanência as perturbações criadas por sua própria presença no campo social em que se inseriam.

Desta forma, entrelaçada com o espaço público contraído de uma pólis restrita, perdurava, na experiência da clandestinidade, uma cidade vivida e sentida onde se desenrolavam práticas e relações que lhes eram próprias, pois a experiência propriamente espacial dos clandestinos foi significativa e nela os subúrbios não teriam desempenhado apenas o papel de cenário circunstancial e inerte, mas sim o de meio de interações e formas particulares de justaposição de mundos no interior do mosaico que constitui a cidade. Tal experiência mobilizava, por um lado, uma dimensão cognitiva, pois o ativista precisava dominar a cidade, conhecê-la intimamente para permanecer anônimo e seguro (Almeida \& Weis 1998:382), recorrendo para isso ao Guia Rex, com o mapa de todas as regiões do Rio, "aprendendo todos os detalhes sobre cada área" (Fernandes Jr. 2004:74-75).

Ao lado desta apreensão utilitária da cidade, desenvolvia-se também uma percepção sensorial e simbólica, quando o militante que vagava pelas ruas "descobria a beleza do outono" (Betto 2000:70), "mapeava todas as padarias e lojas de doces na zona norte da cidade" (Entrevista com M.L., 2009) ou, quando livre das exigências de segurança em relação a horário, "podia estar na rua depois das dez da noite e redescobrir o cheiro de maresia" (Entrevista com C.P., 2008). Os lugares compartilhados pelos militantes e os que com eles interagiam não presumiam, assim, espaço e tempo unitários, mas, ao contrário, incluíam "paisagens subterrâneas de espaços fragmentados, pontos de fratura onde a diferença adentra a ordem urbana" (Crang \& Travlou 2001:175).

Nas narrativas dos militantes, observa-se que estes se defrontaram com um cenário sociológico, para eles, novo - a vizinhança com a amante de um bicheiro preso; a guarda do filho de uma prostituta posteriormente encontrada assassinada; o presenciar de um esfaqueamento envolvendo um policial numa briga de casal; a condução solidária de um bêbado que canta aos brados através da favela; a mulher "pancada" que andava nua pela casa se oferecendo ao casal de militantes que alugava um de seus quartos; o guerrilheiro propositadamente bem vestido e apessoado, cumprindo horários regulares para não chamar a atenção, e que se via detestado por travestis da pensão em que morava por ser apontado, pela dona do cortiço, 
como exemplo de retidão — todas estas são situações típicas de um subúrbio carioca, reconhecíveis, por exemplo, na literatura de Nelson Rodrigues, com suas situações passionais limítrofes, melodramas "que encenam o excesso e a desmesura" (Waldman 1997).

Para analistas da obra deste autor, a propósito, "o traço mais forte que percorre toda a dramaturgia rodriguiana é o trânsito entre universos de valores distintos [...] trânsito demarcado espacialmente pela circulação de personagens através das diferentes áreas da cidade". ${ }^{16}$ Trânsito, pois, entre mundos, pessoas e ideias, mas também entre espaços: os percursos de seus personagens, destaca a crítica literária, propiciam uma espécie de metalinguagem espacial, conotando valores e comportamentos no amplo espectro de possibilidades da Zona Norte à Zona Sul (Dias 2005). ${ }^{17}$ Assim, se Rodrigues descreve, na cidade, um encontro de classes e de espaços que, na realidade, a cidade não conhecera, na experiência da clandestinidade no pós-68, "a realidade teria copiado a literatura". ${ }^{18}$

Conforme destaca Teixeira (1998), “a clandestinidade não representa uma ruptura com o conjunto da sociedade; caracteriza-se por criar um contexto de isolamento relativo"; ao que poderíamos acrescentar: tendo em contrapartida o reconhecimento, também relativizado, por parte dos indivíduos com os quais os clandestinos tinham de se relacionar na sociedade imediatamente circundante dessas personalidades "estranhas". Ou seja, o contexto justificava comportamentos adaptativos tanto por parte dos militantes clandestinos como dos indivíduos que com eles interagiam ou, nos termos de Goffman, a constituição de "consensos operacionais" na definição compartilhada das situações. Tal consenso, porém, era sempre precário: dado que as interações envolvem, em geral, associações de sentido entre expectativas de conduta e "lugares" (Frehse 2008). A casa de cômodos, os corredores e as calçadas compartilhados com moradores e vizinhos, por exemplo, constituíam espaços interacionais significativos na movimentação dos indivíduos, sendo, por vezes, as próprias características físicas dos lugares tidas como signos.

Este foi o caso quando o dono de um barraco afirmou, com gosto, ao jovem militante que acabara de fechar um acordo para o aluguel: "agora você é um favelado!...". Isto porque naquele espaço de sentidos - a favela o militante, deslocado de seu ambiente social original, foi visto como um indivíduo cuja conduta e expressividade não intencional não pareciam adequadas ao grupo de que procurava fazer parte. Avaliando a relação entre o lugar e as condutas, portanto, o integrante da comunidade moral dos que estavam há mais tempo na localidade acionava sua vigilância e seu modo particular de lidar com indivíduos considerados "estranhos" (Frúgoli 2007:28). ${ }^{19}$ 
Por sua vez, em muitos casos, os militantes, tal como pesquisadores em trabalho de campo, procuravam operar sua "indigenização", buscando, na medida do possível, parecer indiscerníveis dos demais atores do jogo local, sem perderem de vista, por outro lado, o caráter relativo de sua integração, observando com atenção o rumo das interações em que se engajavam nos rituais cotidianos (De Sardan 1995:77-78).

Da reelaboração de identidades hibridizadas - no caso dos clandestinos, entre a original e a assumida - teria resultado, assim, um padrão de interação bem específico em que se mesclaram expressões transmitidas e emitidas, ambientes passados e presentes que, conforme sustentava Said (2003) para a experiência correlata do exílio, "são vívidos, reais, ocorrendo juntos como no contraponto". É o que discutiremos a seguir, tendo por base a literatura testemunhal sobre a resistência à ditadura no Brasil e um conjunto de 50 entrevistas com indivíduos que estiveram engajados na luta clandestina na cidade do Rio de Janeiro, notadamente no período $1969-1973 .^{20}$

\section{Padrões de interação e expressão emitida}

A sociologia da clandestinidade é marcada pelas distâncias próprias a uma comunicação problemática entre a cidade vivida e o espaço público. O padrão de interação estabelecido entre os clandestinos e os citadinos com quem os primeiros se relacionavam temporariamente configurava traços de proximidade e distância similares aos da figura do estrangeiro, do viajante ou do estranho, marcados pela mobilidade, por entrarem em contato, por certo período, com grupos com quem não mantinham vínculos orgânicos de parentesco ou ocupação (Frúgoli 2007:16). As interações se davam, ademais, entre sujeitos com campos de experiência diversos — os militantes trazendo, em grande parte, os traços da radicalização então recente do movimento estudantil. O horizonte de expectativas da militância organizada contemplava a perspectiva da obtenção, ao menos no período inicial da experiência clandestina, dos resultados de uma desestabilização do regime de exceção, o que não se estendia, por certo, à população "em geral", caracterizada por observadores da época por estar "em silêncio, numa mistura de alienação e de medo". ${ }^{21}$ É nesse ambiente que os militantes, no conjunto de sua singular mobilidade espacial, integraram, nas cidades, os "agregados casuais e móveis que constituem nossas populações urbanas, [...] em estado de perpétua agitação, varridos por todo novo vento de doutrina, sujeitos a alarmas constantes [...] (Park 1976:45).

Mas como teriam operado, nas particulares condições de "alarma" ao regime de exceção, as "relações sintáticas" unindo as ações dos diversos 
sujeitos em presença? Para tratar desta questão, destacamos a seguir três exemplos selecionados, ilustrativos de certos traços do que seriam padrões específicos de interação entre militantes clandestinos e moradores com quem interagiam, na conjuntura de exceção.

\subsection{A vida familiar de Carlos Nicolau Danielli}

Os vizinhos gostavam daquela família solidária e unida. Na casa em frente, duas jovens estudantes sempre se socorriam da presteza de Danielli para os trabalhos escolares. Na manhã do dia 27 de dezembro de 1972, ele tomou o café da manhã e fumou um cigarro. Marilda já estava no tanque lavando roupa quando ele se despediu e avisou que possivelmente voltaria dali a um ou dois dias. Não voltou. [...] No dia 5 de janeiro de 1973, uma sexta-feira, ela fazia crochê na sala quando ouviu Sérgio Chapelin anunciar com voz grave: “Morto em São Paulo o terrorista Carlos Nicolau Danielli" [...] Sem parentes, sem conhecidos e com três crianças, Marilda resolveu procurar as vizinhas estudantes. Ao saber da verdadeira história, uma delas se dispôs a levá-la com as crianças para o Rio de Janeiro (Bertolino 2006).

Aqui, a relação estabelecida na situação ligava por cordialidade as estudantes à família do vizinho militante, e a ruptura na definição da situação foi enunciada por iniciativa do próprio sujeito clandestino. O consenso operacional que vigorava baseava-se até então no controle cuidadoso da comunicação quando a "plateia" vizinha estava presente. Foi a presunção de compreensão que a mulher do militante assassinado atribuiu às vizinhas que a levou a expor a situação até então reservada aos bastidores, redefinindo a cena dramática em bases que, inclusive, contraditavam perigosamente a versão oficial da ditadura exposta na mídia.

\subsection{A distinção de Brasilina}

Nós saímos da classe média de zona sul; éramos menininhos certinhos. Éramos despojados e mudávamos rapidamente; por mais que a gente quisesse, não se perde as características, toda uma maneira de falar. Mas imagino que eles imaginassem que qualquer coisa não encaixava. [...] Era como uma casa de cômodos. Tinha uma casa melhorzinha na frente, onde morava um casal jovem e atrás tinha dois ou três quartos — nós num quarto, a amante de um bicheiro que estava preso em outro. Um dia estava a polícia civil na porta de casa. 
E nós... entra não entra, entra não entra... A gente se dava bem com a vizinha da frente. O que era? O bicheiro era levado pela polícia na rádio-patrulha para transar com a amante. Ela morava num quartinho bonzinho, com televisão. $\mathrm{O}$ nosso quarto era muito pior. $\mathrm{O}$ da frente era melhor porque era uma casinha mesmo, sala e quarto modesta, onde morava a Brasilina - nunca esquecerei. A gente tinha uma boa integração. Com a Brasilina a gente comia junto, conversava. Ela não trabalhava, tinha criança. Ela queria sair dali, não aguentava a prostituta, e propôs à gente morar junto, alugar uma coisa melhor, uma casinha de subúrbio. Ela via que a gente era bem-educado, a gente saía todo dia pra trabalhar. A amante do bicheiro não era de trabalhar, era sustentada, ficava em casa, pintando a unha, se vestindo, passeando. A Brasilina ficava com medo dela - achava uma mulher vulgar - e se identificava com a gente, que fugia ao padrão (Entrevista com C.H., 2008).

Tipos recorrentes de encontros são fundados sobre a hipótese de que seus participantes são iguais segundo certos critérios morais, mentais e fisionômicos (Goffman 1974:96). Entre os locatários da casa de cômodos em causa, a vontade de distinção em relação à "amante do bicheiro" levou Brasilina a construir uma identificação com o casal de militantes educados, a ponto de propor compartilhar com eles uma nova moradia, procurando afunilar, consequentemente, os critérios de participação no "consenso operacional". Vigorou assim o que Barthes chamou de "efeito espelho na divisão do campo social" (Barthes 2002:117), através de uma mímesis da respeitabilidade burguesa, pois como parte de um agrupamento determinado por contingências, entre colocatários tende a elaborar-se um "Telos comum fazer-se reconhecer como figura do respeitável" (Barthes 2002:84). ${ }^{22}$

\subsection{O frango de Ottoni}

Havia dois outros inquilinos na pensão. Um nissei paulista, Tatsuo, uma raridade no Rio, que trabalhava numa fábrica de tintas, e um marinheiro, da Marinha Mercante, que aparecia quando o navio se encontrava fundeado na cidade. Tatsuo, ao saber que eu era de São Paulo, ensaiou uma aproximação. Queria mantê-lo à distância, até porque nisseis chamavam muito a atenção no Rio e eram muito visados. [...]. Orgulhoso, eu também evitava os convites porque não tinha dinheiro sequer para pagar uma cerveja. Observador, Tatsuo foi percebendo o meu jeito. Deve ter pensado que o orgulho era um impedimento ao contato. Orientalmente sutil, convidou-me para uma cerveja. No primeiro dia, dividimos as despesas. Outras vezes, insistiu em pagar a conta. A generosidade do vizinho 
Tatsuo deixava-me desarvorado. Impedia que eu seguisse normas de segurança e o próprio bom senso, que não recomendava andar com um nissei. Tatsuo convidou-me para passar um fim de semana em Rio da Prata, um subúrbio da Zona Norte do Rio. Era um bairro de operários. A dona da casa era uma viúva e o filho trabalhara na tecelagem. Fui recebido com calor e carinho, como o amigo do Tatsuo, de quem já tinham ouvido falar. Filhos, filhas, amigos e agregados vieram apresentar-se. Logo depois, fomos para a praça, onde rolava uma pelada. Convidaram-me para jogar. Logo estava íntimo. Virei juiz nas peladas. Noite de sábado, deixei as normas de segurança de lado e saí com a turma para roubar galinhas. A técnica era refinada. Levávamos um pau de vassoura e um saco de estopa molhado. Entrávamos no galinheiro, cutucávamos as patas da galinha, que logo passava para o cabo da vassoura e era colocada no saco, onde ficava quietinha. No dia seguinte, convidávamos o dono do galinheiro para uma galinha ensopada (Fernandes Jr. 2004:77-80).

O acesso a certas regiões da vida do clandestino é normalmente controlado por ele, a fim de evitar que a "plateia" veja os bastidores e impedir que estranhos participem de uma representação que não lhes é endereçada. No caso narrado por Fernandes, o militante buscou controlar a impressão que causava nos vizinhos, evitando, sem sucesso, uma aproximação dos demais com sua própria fachada: a "generosidade, o calor e o carinho" dos outros participantes da interação sinalizaram sua incorporação ao grupo operário, assim como a seus critérios de justiça — na qualidade de juiz de futebol e de partícipe da transgressão lúdica de normas legais correntes.

No primeiro exemplo acima exposto, portanto, a conexão entre militantes clandestinos e vizinhos fez-se através da transmissão de conhecimento, de uma relação cordial de aprendizagem. No segundo caso, a aproximação com o casal de militantes deu-se na busca de distinção de Brasilina em relação ao status da terceira co-habitante da casa de cômodos. No terceiro caso, a confiança no "consenso operacional" estabeleceu-se a tal ponto que se inverteu a situação, o não militante incitando o militante clandestino a participar de práticas de algum modo "transgressivas".

Os casos acima selecionados são alguns dentre aqueles em que as interações estabelecidas diferem daquelas estritamente instrumentais firmadas pelos clandestinos com suas vizinhanças — justificadas "por razões de segurança" ou para "que os vizinhos não desconfiassem". Eles evidenciam, ademais, a irrupção — também não instrumental — de traços da identidade original dos clandestinos. Assim, se nessas relações se faziam presentes traços dos universos culturais originários dos sujeitos, ainda que reelaborados para os fins da interação social ou, como nos termos de 
Souza Bastos (2004), se os "arranjos sociais anteriores foram renegociados e reproduzidos de outras formas num modo de vida sociocultural diferente do legal, criando novas redes de interação", o mesmo parece ter ocorrido, em certos casos, no outro polo da relação, a saber, o dos moradores das vizinhanças dos lugares habitados por clandestinos. Este tipo de reelaboração explicaria, por exemplo, a presteza com que a estudante vizinha dos Danielli reagiu ao ser informada daquele drama familiar, ao mesmo tempo surpreendente e temível; o mesmo teria se dado com o desejo de distinção manifesto por Brasilina na convivência com o casal de educados militantes e sua pretensão de mudar-se para compartilhar com eles nova moradia, ou ainda com a insistência com que o operário Tatsuo traduziu a "expressão emitida" por Fernandes, visando à possibilidade de sua integração à sua rede "transgressiva" de interação.

Assim, muitos clandestinos não teriam conseguido disfarçar, em particular, os traços de sua maior escolarização. Em certas situações, isto significava problema: a militante locatária dava aulas de matemática à filha de 15 anos da proprietária do quarto, mas, oficialmente, dizia ser aluna de Artigo 99; no quarto que dividia com a cozinheira, a clandestina temporariamente empregada como babá em família de classe média de subúrbio lia todos os jornais e revistas antes de jogá-los fora, tendo de ouvir da colega: “-É muito exibida. Ainda se fosse revista de amor... Nem vai na escola com a gente. Que tanto você lê?" (De Luca 2002:240 ).

Mas, para outros, a dificuldade de controlar as impressões sobre sua escolaridade teria gerado efeitos não intencionais de atração sobre os não militantes com quem interagiam. São vários os exemplos: militante "deslocado" considerado "muito sabido" e apelidado de Rui Barbosa pelos demais operários de fábrica era chamado a fazer o Imposto de Renda dos colegas, inclusive do encarregado: "- Ceará, sobe lá na minha sala. Eu pensava que ia levar um esporro, e ele: - Olha, faz meu imposto de renda aí pra mim"; outro militante fazia a contabilidade do taxista vizinho; um clandestino se destacava, na consideração de seus paupérrimos colocatários, por "saber escutá-los" no ambiente conflituoso do cortiço em que moravam; a ex-operária que ascendera socialmente ao casar com seu ex-patrão, dono de uma pequena confecção, fazia insistentes convites exclusivos aos clandestinos locatários de sua lotada casa de cômodos para que trouxessem amigos para compartilhar o Natal e outras festas; a idosa, na casa de quem duas militantes passavam horas dos dias escondidas a acompanhá-la nas costuras, propôs que estas passassem a morar com ela por avaliá-las com "jeito de moças direitas e recatadas". O aprendizado, cabe ressaltar, deuse para muitos militantes no sentido inverso: "Foi uma experiência impar; 
foi uma época bonita"; "eu conheci a vida de vários ângulos que eu jamais teria possibilidade de conhecer"; "passei a entender um pouco da realidade brasileira, de dentro"; "eu fui compreendendo qual era a dinâmica daquela vizinhança; foi uma coisa que eu não conhecia - uma vida nova, boa e bonita; uma coisa boa, bonita e barata e que ficou pra mim..." (Entrevistas com M.L, J., A. e J). ${ }^{23}$

No entanto, dificilmente aproximações desta natureza, quando ocorriam, se materializavam em ampliação da rede de ação política contestatária, dada a intervenção frequente das restrições na esfera pública, que faziam abortar a possibilidade de as microrrelações se politizarem. Assim como qualquer outro sujeito social, o militante clandestino desempenhou mais do que um papel, contando com a "segregação dos públicos" para se salvar das contradições. Como assinala Goffman, aqueles diante dos quais se desempenha um dos papéis não são correntemente os mesmos diante dos quais se desempenha outro, o que permite encarnar diversos personagens sem desacreditar nenhum (1974:96). No caso particular da vida clandestina, para os públicos imediatos da convivência social cotidiana, por um lado, as "expressões transmitidas" pelos militantes tinham de ser encarnadas em personagens aparentemente despolitizados, enquanto, por outro lado, no campo da luta política, o seu acesso à esfera pública era bloqueado pela ação repressiva. A distância entre o perfil de seus diferentes personagens identidades assumidas e identidades "originárias" — era assim condicionada pela distância entre a esfera macropolítica do estado de exceção e os palcos microssociológicos das interações correntes.

De todos os depoimentos recolhidos, podemos inferir que as situações de interação descritas denotam a vigência de uma comunicação intrinsecamente problemática entre os militantes e os habitantes, notadamente dos subúrbios, com quem compartiam contatos face a face - próxima do que Goffman (1993:66) chama de "disfórica", ou seja, portadora de uma tensão interacional: por um lado, interclassista, por outro, atravessada pelas dificuldades de acesso da militância à esfera pública, dada a vigência de uma ruptura radical dos canais de ligação entre as instâncias micro e macropolíticas. ${ }^{24}$

Em cada ruptura definicional de situações, quando a condição militante de algum modo se revelava, saindo dos bastidores para a própria cena, passando de um enquadramento primário a um enquadramento secundário das situações, colocava-se virtualmente a possibilidade de politização das microrrelações, justificando tanto manifestações de temor ou empatia, como de perplexidade ou eventual delação dos que haviam sido erigidos em "suspeitos". 
Dado o caráter "impreciso e movediço dos limites entre as dimensões pública e privada prevalecente nos regimes de força" (Almeida \& Weis 1998:327), em diversos momentos as situações de interação moviam os limites entre o público e o privado. Este teria sido o caso quando as interações desenvolvidas por clandestinos com pessoas comuns eram afetadas por fatos que davam a conhecer o caráter político de suas atividades, ou seja, que eles agiam "para influenciar, conquistar ou exercer o governo" (ibidem). Foram diversos os desdobramentos possíveis para tal situação. No caso de militantes envolvidos em trabalho armado, encontraremos desde casos de solidariedade ativa com perseguidos, com um risco pessoal assumido pelo não militante, até comentários circunstanciais naturalizantes de situações de imprevidência, quando, por exemplo, armas eram esquecidas em balcões de bar - "olhe, não se larga os instrumentos assim de qualquer maneira, não", disse o dono do bar - passando pela cumplicidade passiva dos não militantes com a fuga dos clandestinos perseguidos ou a solidariedade oferecida sob a proteção do anonimato - como no caso dos vários telefonemas de alerta para a família de um preso que havia gritado na rua, no momento de sua prisão, seu nome e telefone da família.

Nos casos em que a militância se dedicava a abrir contatos políticos junto à população, tais situações colocavam o ativista ante a necessidade de proceder a um cálculo de risco - desenvolver o contato adquirido em situação incerta de segurança, com a possibilidade de subsequente denúncia e prisão, ou abdicar de desenvolvê-lo, perdendo, por precaução, a oportunidade de ampliar sua rede de ação. Dar a conhecer a situação de militante a não militantes constituía, pois, em certas circunstâncias, uma condição de relativa publicização da ação política, a abertura de uma esfera de comunicação na qual se poderia "dizer aquilo que não podia ser dito diante do poder" (Scott 2004) ${ }^{25} \mathrm{E}$ caso tal conhecimento se tornasse acessível a uma comunidade mais ampla, poderia abrir-se a possibilidade de que atividades clandestinas fossem eventualmente conectadas à "rede de redes" que constitui a cidade (Hannerz apud Frúgoli 2007:46), viabilizando a articulação da ação contestatária a novos âmbitos da sociedade heterogênea que constitui o espaço urbano.

Nas relações microssociológicas aqui discutidas encontramos, por certo, marcas de fenômenos sociais inscritos em escalas espaciais mais amplas e em tempos sociais mais longos, configurados no que certos autores chamam de mecanismos "macro-micro", nos quais "processos em grande escala criam oportunidades e riscos para os diferentes atores, que costumam incluir essas oportunidades e riscos como parte das razões para agir" (Hedstrom \& Swedberg 1998 apud De Landa 2006:128) ou, nos termos de Benjamin, que nos permitiriam eventualmente descobrir, na análise do pequeno momento 
individual, "o cristal do acontecimento total" (Benjamin 2006:503). Cabe aqui a pergunta: podem as observações da microssociologia da clandestinidade fornecer elementos para entender sua articulação com os processos sociais mais amplos nos quais se inscrevem?

A saída da legalidade foi para muitos um meio de, a partir do AI-5, fazer chegar à população, seja por atividades de agitação política ou de propaganda armada, as mensagens que haviam sido emudecidas pelo fechamento da esfera pública. Efetuava-se assim um movimento que não parece poder ser enquadrado com propriedade em modelos de ação como aquele chamado por Hirschman de "saída e voz", ou seja, o abandono pelos atores do campo do conflito - "saída" — ou a enunciação pública, por eles, de seu protesto crítico - "voz". Não se tratava, no caso, de pôr em prática nem o esquema dito de "relação inversa entre saída e voz" — retirar-se do conflito por nele não se poder fazer ouvir — nem tampouco de "colaboração entre saída e voz" — retirar-se da cena do conflito para, por sua simples ausência, se fazer ouvir (Hirschman 1996:20-22). Isto porque não houve, naquela conjuntura, um simples abandono do espaço público restringido ("saída"), mas um deslocamento político da esfera legal para a ação clandestina, na busca de novos meios e canais que permitissem às vozes críticas ao regime se fazerem ouvir.

Configurou-se, então, em paralelo à oposição pública — consentida uma oposição clandestina que se avolumou a partir do AI-5. Esta última tinha, por sua vez, uma face pública — uma "fachada" — constituída, digamos assim, pela soma das fachadas de todos os militantes clandestinos, e "bastidores" formados pelo conjunto das práticas políticas não aceitas pelo regime de exceção. É nessa condição particular que diremos que cada um dos membros da oposição clandestina operou com uma dupla fachada ${ }^{26}$ — a de seu personagem público e a de sua identidade oculta, esta última, por certo, baseada em sua fachada no sentido goffmaniano original. No plano do Estado, igualmente, podemos considerar que a fachada pública restringia-se, com intensidade particular em relação aos modos de operação das instituições correntes, a uma encenação congressual e a um sistema legal "de fachada", enquanto seus próprios bastidores foram significativamente ampliados, já que neles operavam as práticas de força intensificadas, entre as quais as instituições da tortura, da censura e do manejo arbitrário do aparelho estatal. Nesse sentido, podemos dizer que os conceitos de fachada e de bastidores de Goffman têm, para nosso objeto - por extensão e guardadas as devidas distâncias de escalas e contextos - certa capacidade de esclarecimento tanto no plano micro como no macrossociológico, cabendo considerar que a política como um todo sofreu uma transferência de parte considerável de seus mecanismos da esfera pública para as esferas clandestinas no que diz respeito à política oposicional e à política estatal. 
Assim é que, nas condições da luta política clandestina contra a ditadura, os diferentes momentos de publicização da causa contestatária se deram através de rupturas situacionais - seja por meio de ações espetaculares que não podiam ser facilmente escondidas da mídia, seja quando a condição militante se tornava subitamente visível para grupos de sujeitos sociais com quem os clandestinos interagiam imediatamente. Em muitos casos, os desdobramentos problemáticos dessas rupturas eram sintoma das dificuldades de se tornar pública a contestação ao regime; com frequência, em tais episódios, o movimento em direção a uma microarena pública ${ }^{27}$ emergente era abortado. Desta forma, a publicização foi evitada, por exemplo, pelo militante que, envolvido em um trabalho de organização em favelas, preferiu afastar-se de um adversário do regime de exceção, posto que este, sob a ação do álcool, perdia a autocensura e "falava demais"; um trabalho de organização de associações desenvolvido a partir da Igreja foi interrompido quando se soube que um motorista do DOI-CODI, um dos principais órgãos repressivos do estado de exceção, tinha ligações com um membro do grupo; companheiras de uma militante deslocada para uma fábrica revelaram, após o fim da ditadura, que seu grupo achava que havia algo estranho, sabia de sua condição, mas nada dizia para não constrangê-la — estavam "de olho nela para que, se acontecesse alguma coisa, poder fazer alguma coisa"; a publicização ficou latente, por outras vias, na inversão de posições em que um guerrilheiro urbano foi "recrutado" por um grupo operário para a prática lúdica de pequenos furtos.

O alcance do estrangulamento das condições para o exercício da crítica pode ser medido pelo fato de que, segundo relatos de militantes deslocados para a produção fabril, os operários tendiam a achar que era "dedo duro" o colega que atacasse o governo ou falasse de política, supondo que este comportamento fizesse parte das artimanhas do poder para descobrir oponentes ao regime. Igualmente, a família com quem morava um militante residente em favela - que se declarava "muito abertamente" contra o regime - espalhava que ele era "maluco" para protegê-lo da vigilância de um capelão do exército conhecido nas redondezas como "dedo-duro".

Quanto a esse bloqueio da liberdade de comunicação e da constituição de arenas públicas, registra Herbert Daniel que "um hábito da clandestinidade, desde sempre", era o de escrever e ir "queimando as páginas viradas, o que dava a sensação de escrever fumaça. Assim, índio clandestino, enviava meus sinais de fumo" (1982:28).

As situações problemáticas da militância clandestina em contato com seu "público" imediato ilustram, em particular, o modo como operava a instituição geneticamente truncada de arenas públicas frustradas. É expressiva 
a esse respeito a cena do filme Cabra cega, dirigido por Toni Venturi, em que o militante clandestino em crise, por muito tempo enclausurado em um "aparelho", é "presenteado" com uma visita ao terraço elevado de um edifício, de onde estende as mãos tentando simbolicamente se comunicar com a pólis aparentemente silenciada e ensurdecida.

Mesmo no caso da militância clandestina daqueles que — via "trabalho de massa" - buscavam laços diretos com a cidade política, o macrocontexto interveio permanentemente como obstáculo à constituição de arenas públicas no espaço social mais amplo, assim como à inscrição das ações num tempo histórico suficientemente contínuo para dotá-las de sentido. Isto porque, em termos de temporalidade social, o sentido de um "trecho de palavra" depende da totalidade da "história" que tende a se constituir a posteriori, circunscrevendo o sentido de seus componentes. O contexto costuma incluir "uma estrutura de antecipação das fases por vir e uma estrutura de retenção das fases já cumpridas na troca conversacional" (Cefai 2003:559). Ora, esse processo de construção histórica do sentido das ações e das falas é, nos regimes políticos de exceção, permanentemente, objeto de violenta descontinuidade.

\section{Considerações finais}

Os encontros aqui estudados - como parte do que chamamos acima de "zona cinzenta urbana" na relação da cidade com a ditadura - constituem microcontextos de uma ação coletiva sempre frustrada pelos obstáculos aos processos de publicização da crítica. É através desses processos que a topologia a que nos referimos no presente texto - aquela que descreve a diferença de "altitude" entre os planos da ação militante e a "sociedade" poderia ter se mostrado movente, dependente como ela tende a ser das condições e das formas históricas de gestão das distâncias entre os sujeitos sociais. Adestruição sistemática das arenas públicas concorreu, portanto, para que os militantes fossem recolocados permanentemente em um plano "aéreo" em relação ao tecido social. Os impasses criados pela publicização truncada permite-nos atentar, ademais, para como a ditadura é via de regra produzida num movimento constante de destruição, em distintas escalas, de arenas públicas emergentes, seja através da censura à imprensa, da dissolução de organizações sociais, do enclausuramento de críticos e oponentes, da exposição exibicionista do poder arbitrário da máquina repressiva ou da internalização do medo em larga escala na população.

"Em todo sistema social, há pontos onde os princípios de organização entram geralmente em conflito" (Goffman 1974:100). Este conflito, por certo, é particularmente agudo quando uma militância política contestatária se 
engaja no contexto de um regime de exceção. Em lugar de deixar o conflito se exprimir no seio das interações correntes, o clandestino "sacrifica sua identidade por uns tempos, ou para uma interação, mas os princípios são salvos". Por vezes, "ele quase se desespera para que princípios pouco acordes entre si possam operar ao mesmo tempo". "Com isso", conclui Goffman, referindo-se, no quadro geral de suas pesquisas, à vida social corrente, "a estrutura social ganha em leveza; e o indivíduo perde somente sua calma" (1974:100). Ora, no contexto específico da luta contra a ditadura, ao contrário, foi o peso da estrutura social policiada que exigiu da militância clandestina um excedente de flexibilidade ante o silêncio e a calma aparentes da cidade.

Seja pelo medo internalizado através do terror da repressão, seja pela vigência de um "texto oculto" por meio do qual os grupos que carecem de poder reforçam as aparências hegemônicas enquanto não vislumbram forças para recorrer a uma rebelião (Scott 2004), ou ainda pelo desapreço à esfera política, dado que os agentes do golpe de 64 e do AI-5, a despeito de desencadearem ações destinadas a destruir as organizações populares e a barrar as dinâmicas democratizantes em curso, pouco teriam alterado substancialmente a condição histórica de subcidadania dos excluídos até então prevalecente (Abramo \& Maués 2006:61-62), a indiferença política foi o que os militantes registraram como estado social predominante naquele período. ${ }^{28}$

No entanto, a despeito dos sinais de indiferença, os clandestinos emitiam "seus sinais de fumaça", como personagens estudados pela antropologia dos viajantes, para a qual, a fim de não parecer um intruso ou um invasor estrangeiro que veio se apropriar da identidade de outros, o viajante é levado a apagar ou a transformar sua própria identidade: a modificar seu costume para melhor se fundir no ambiente, a mudar sua linguagem, a remodelar suas maneiras de viver e de sentir. Em suma, "a pagar com uma certa impostura o preço de sua autenticidade" (Lepape 1998).

Referindo-se à chegada do homem à Lua e às representações deste fato nas manifestações culturais brasileiras no final dos anos 1960, o crítico José Miguel Wisnik sugeriu que "a viagem para fora da Terra alterou nossa consciência, como se uma parte desta se desprendesse do planeta e nos visse de longe" (Wisnik 2005:27). Em paralelo, através de outros tipos de operação de distanciamento, tentando administrar as diferenças de "altitude" entre o plano da ação política e o da vida social, a militância clandestina procurava então trilhar, nas ruas da cidade, o chão concreto de suas utopias. 
Henri Acselrad é professor do Instituto de Pesquisa e Planejamento Urbano e Regional da Universidade Federal do Rio de Janeiro. E-mail: <hacsel@uol.com.br>

\section{Notas}

* O presente texto resulta do projeto de pesquisa 'Clandestinidade e cidade', apoiado pela Faperj e realizado com a participação das pesquisadoras Gilberta Acselrad e Iara Ferraz

${ }^{1}$ No caso argentino, por sua vez, o que se tem destacado são os "lugares de memória" - antigos campos de concentração e locais de massacres, sacralizados e investidos de um trabalho de rememoração coletiva através da instituição de monumentos, museus, centros culturais. Cf. L. S. Catela (2001), em particular o capítulo 4, "Territórios de memória".

2 "Apesar de incursões e ações no campo, a guerrilha no Brasil é urbana" (Ferreira 1996:13). Conforme M. Ridenti, "Depois do fechamento político imposto pelo AI-5, no final de 1968, com as ondas de prisões, com o cerco policial e com a imersão geral das esquerdas na 'luta armada' e o distanciamento da implantação almejada da guerrilha rural, as teses sobre o papel das ações armadas urbanas foram deixando de vinculá-las apenas à preparação da guerrilha no campo."; "Na memória de um combatente 'o grande objetivo era a guerrilha rural'; a guerrilha urbana jamais foi para qualquer organização senão 'um método secundário' . Não obstante, foi pela atividade nas cidades que os grupos guerrilheiros se notabilizaram" (Ridenti 1993:49-53).

${ }^{3}$ Ferreira chamou a atenção para os limites de parte da literatura que discute a experiência das forças que resistiram à ditadura no período 1968-1973 a partir do pressuposto de sua derrota, alertando para o fato de que "[...] qualquer avaliação fundada no presente e, portanto, construída com dados elaborados a posteriori, não incorpora a dimensão sociológica e histórica desses projetos e dos projetos individuais que nele se confundem. É, portanto, comum julgar-se a 'eficácia' ou a 'validade' da ação das organizações clandestinas pelo resultado de sua estratégia, não se levando em consideração o alcance de sua força simbólica e política" (Ferreira 1996:26).

${ }^{4}$ Para Goffman, as situações de interação são aquelas em que duas ou mais pessoas estão copresentes, comunicando e controlando mutuamente suas aparências, sua linguagem corporal e suas atividades. $\mathrm{O}$ "consenso operacional" é aquele no qual os participantes de uma interação contribuem, em conjunto, para compartilhar uma única definição geral da situação, o que implica não tanto um acordo real 
quanto às pretensões de cada pessoa, mas um acordo real quanto à conveniência de se evitar um conflito aberto na definição da situação (Goffman 2008:18-19). Nas situações de interação, os indivíduos exprimem-se de formas distintas: a "expressão transmitida" é aquela governada pelo próprio sujeito, e a "expressão emitida", aquela não governada. A primeira abrange os símbolos verbais, ou seus substitutos, que ele usa propositadamente ou tão só para veicular a informação que ele e os outros sabem estar ligada a esses símbolos. Esta é a comunicação no sentido tradicional e estrito. A segunda inclui uma ampla gama de ações, que os outros podem considerar sintomáticas do ator, deduzindo-se que a ação foi levada a efeito por outras razões diferentes da informação assim transmitida (Goffman 2008:12).

${ }^{5}$ Koselleck ressalta que não existe uma experiência que não se relacione com um horizonte de expectativas, da mesma forma que não existe expectativa que se constitua sem fixar-se num campo de experiências. A experiência é o passado-presente, aquilo realizado no passado e lembrado no tempo presente, tornado memória. O horizonte de expectativas, por outro lado, situa-se no campo do não realizado, constituindo-se como algo incerto, não experimentado. O passado muitas vezes contribui para as expectativas que se tem do futuro, mas ele nunca será responsável por determiná-las (Koselleck 2006:307).

${ }^{6} \mathrm{O}$ levantamento realizado no âmbito da pesquisa Brasil Nunca Mais, por iniciativa do reverendo James Wright, debruçou-se sobre 707 processos políticos abertos entre 1964 e 1978 envolvendo 17.420 pessoas nas categorias denunciados, indiciados, testemunhas e declarantes, sendo que entre aqueles sobre os quais se dispunha da informação sobre residência, 2.409 declararam morar no Rio de Janeiro (Cf. D. A. Reis Filho 1989:161). Segundo o mesmo levantamento Brasil Nunca Mais, entre os processados, 1.210 residiam na cidade do Rio de Janeiro (Ridenti 1993:241).

${ }^{7}$ Segundo depoimento de um ex-militante, "à medida que o cerco da repressão aumentava, mais nos embrenhávamos pela Zona Norte, mais perto procurávamos ficar do povo, da população explorada que tencionávamos representar e da qual cada vez mais nos afastávamos politicamente. A Zona Norte foi uma espécie de última retaguarda da esquerda [...]". Deu-se uma "fuga em direção aos subúrbios da Central do Brasil, para as cidades da Baixada Fluminense, para Campo Grande, Bangu, Cascadura, Caxias, Meriti, Nova Iguaçu, terras desconhecidas e de difícil circulação, mas que nos pareciam um refúgio mais seguro do que os repisados e atraentes caminhos da Zona Sul" (A. Caldas 2004). Lima e Arantes (1984:113) confirmam: "Nas cidades [os militantes] procuravam os bairros mais pobres para morar [...]".

${ }^{8}$ Em fins de 1969, a imprensa carioca noticiava: "Um dos trabalhos de envergadura das autoridades do DOPS, nestes últimos meses, foi catalogar os apartamentos existentes no Rio, especialmente na Zona Sul, destinados a aluguel de temporada, que eram utilizados pelos subversivos para suas campanhas-relâmpago. Ultimamente, tanto proprietários como síndicos e os próprios porteiros dos edifícios onde existem apartamentos para alugar por temporada, antes de acertar o contrato, estão procurando as autoridades para informar-se dos locadores, o que dificulta a ação dos terroristas. Assim, 
estão eles agora deixando a zona sul e preferindo o perímetro suburbano, e até a área rural onde existam casas, mesmo isoladas, que trazem mais facilidade à sua missão. Tais casas estão sendo observadas de helicóptero — como foi a da Barão de Petrópolis, onde esteve sequestrado o embaixador norte-americano Burke Elbrick" (Cf. "Subversivos da Rua Aquidabã eram da linha de Marighella", jornal O Dia, 23/11/1969, p. 20).

${ }^{9}$ A relativamente baixa participação de indivíduos de classes de menor renda na resistência que se articulou a partir de 1968 pode ser explicada, em grande parte, pela violência do ataque da ditadura que, desde o seu início em 1964, investiu na desmontagem das organizações de trabalhadores na cidade e no campo.

10 "[...] As evidências são claras: era jovem a maioria dos militantes e simpatizantes das esquerdas após 1964, principalmente das esquerdas armadas, situação contrária àquela anterior ao golpe" (Ridenti 1993).

${ }^{11}$ Várias organizações clandestinas efetuaram políticas de deslocamento no período, seja para o trabalho fabril seja para o campo, como o PC do B, a AP, a ALA Vermelha, a POLOP e as Dissidências do Partido Comunista (Cf. D. A. Reis Filho 1989:175).

${ }^{12}$ Baseamo-nos aqui, principalmente, nas narrativas dos militantes sobre sua experiência. É importante considerar, portanto, que as falas provêm de sujeitos que podem ter ficado propensos a idealizar as condições do apoio social que obtinham, atribuindo às suas ações mais legitimidade do que estas efetivamente obtiveram ou, então, a acentuar a falta deste apoio para magnificar o peso de seus feitos. Levamos em consideração, porém, o fato de que a consciência da derrota da resistência no período 1968-1973 venha sendo, antes, correntemente associada a uma autocrítica mais ou menos politizada das estratégias então adotadas, favorecendo, por um lado, certa sobrevaloração de fatores conducentes ao reduzido apoio social à luta contra a ditadura (tais como as benesses do "milagre econômico") e, por outro, uma subestimação do peso do fator repressivo como inibidor de uma adesão mais expressiva à resistência. Na conjuntura em que foram feitos os depoimentos, acreditamos poder supor que os efeitos acima considerados tenham exercido entre si certa compensação.

13 "Éramos pessoas perigosas, nitidamente perigosas", afirmou a dirigente política Vera Silvia Magalhães a respeito do risco que corriam os que se aproximavam dos que militavam contra a ditadura (Cf. entrevista de Vera Silvia Magalhães 2005). Cabe ressaltar que a criação do Banco Nacional de Habitação (BNH), em 1964, consubstanciava uma tentativa do regime militar de isolar as oposições e conquistar legitimidade política junto às classes trabalhadoras, como deixa claro o discurso de Sandra Cavalcanti, ex-secretária de Ação Social da Guanabara e primeira presidente do $\mathrm{BNH}$, ao destacar a importância da política habitacional para a manutenção da ordem pública posterior ao golpe: “[...] Nós achamos que a Revolução vai necessitar de agir vigorosamente junto às massas. Elas estão órfãs e magoadas, de modo que vamos ter que nos esforçar para devolver a elas uma certa alegria. Penso que a solução dos problemas de moradia, pelo menos nos grandes centros, atuará de forma amenizadora e balsâmica sobre suas feridas cívicas" (Cavalcanti apud R. Compans 2010). 
${ }^{14}$ Cf. W. Benjamin (2006).

${ }^{15}$ Segundo depoimento de Edgar Morin, na experiência da resistência francesa, “[...] A vida na clandestinidade era uma mescla de medo e excitação. Certamente eu tinha medo da prisão (o risco era real), da tortura e de confessar tudo que os torturadores quisessem. Eu sentia a exaltação de participar de uma guerra, e a alegria de novamente conquistar vitórias" (Cf. Morin 2000, "Dos demônios - atelier ao vivo do pensamento de Edgar Morin").

${ }^{16}$ Ver A. Facina (2004:201-203).

17 “Em Nelson Rodrigues, nas memórias, a travessia da cidade, da Zona Norte ao Centro e à Zona Sul, por meio de transporte público ou em percursos a pé, é uma constante. [...] A construção dos roteiros da cidade [...] testemunha uma comum destinação da linguagem como 'prática do espaço'" (Dias 2005:3).

${ }^{18}$ Ao caracterizar a obra de Nelson Rodrigues, Ângela Maria Dias (2005:7) sublinha como, na "correspondência estreita entre arte e vida que caracteriza o seu percurso existencial e artístico", as crônicas deste autor "ao mesmo tempo em que se ocupam da cidade vivida e sentida, desenham o espaço público da pólis, e nele configuram o que poderíamos considerar um conjunto de atitudes". Não por acaso, Nelson Rodrigues havia mencionado a clandestinidade como um dos temas que pretendia incorporar a seu trabalho. Disse ele: “Quis o destino que meu filho Nelson, na altura dos 24 anos, entrasse na clandestinidade. Talvez, um dia, eu escreva todo um romance sobre a clandestinidade e a prisão do meu filho" (Cf. Nelson Rodrigues apud Ângela Maria Dias 2005:11). Cabe ressalvar que em suas crônicas, a propósito da esquerda, Nelson Rodrigues esmerava-se em caricaturar e reprovar a intelectualidade por esta nada conhecer dos subúrbios e dos pobres.

${ }^{19}$ Casais de muito pouca idade, duplas de moças que trabalhavam e não namoravam, histórias que não combinavam com aparência e modo de falar produziam, provavelmente, na percepção dos militantes, impressão de estranhamento junto aos moradores com quem interagiam.

${ }^{20}$ Além de fazer uso das entrevistas realizadas entre os anos de 2008 e 2011 com 50 ex-militantes clandestinos que atuaram na cidade do Rio de Janeiro entre 1969 e 1973, a pesquisa que deu lugar ao presente texto contou também com entrevistas constantes do acervo do Grupo de Estudos da Ditadura do IFCS/UFRJ e com depoimentos já previamente publicados. No caso dos depoimentos não previamente publicados, registramos, após as citações, as iniciais dos nomes dos entrevistados.

${ }^{21}$ Ao se referirem a um grupo de grande visibilidade social, os jogadores de futebol da seleção brasileira de 1970, o jogador Tostão afirmou: "Não havia nenhuma proibição oficial de falar da ditadura [...], porém existia um silêncio, uma mistura de alienação e de medo" (Cf. Tostão, "1968, também se jogava futebol", Folha de São Paulo, 01/06/2008, p. D7). Outros depoimentos sugerem a operação de uma espécie de correia de transmissão do temor e do silêncio: o antropólogo Gilberto Velho, em 
observação posteriormente reproduzida por Marcelo Ridenti, testemunhou situação em que, após prisão e morte de militantes num prédio de apartamentos, "já na manhã seguinte ninguém comentava o assunto no edifício" e "o próprio porteiro fez questão de esclarecer que o síndico tinha recomendado que não se falasse no caso" (Albuquerque 1977:150 apud Ridenti 1993:254).

${ }^{22}$ A propósito, cabe sublinhar que eram comuns as situações em que clandestinos e vizinhos ou co-habitantes de casas de cômodos assistiam juntos às novelas televisivas, justamente aquelas a que Maria Rita Kehl se referia como operadoras da "solidão em cadeia": "Ao homem expropriado de sua condição de ser político [...], a TV absorve e canaliza suas aspirações emergentes de ascensão social e felicidade via consumo e, cúmplice, coloca no vídeo sua imagem e dessemelhança, capitalizando seus desejos para o terreno do possível" (Kehl 2005a:409).

${ }^{23}$ Para o caso dos deslocados (établis) franceses, Neveu reporta que eles consideram, analogamente, ter obtido "uma visão mais realista e concreta das situações, uma capacidade de se pôr no lugar daqueles com quem trabalhavam, libertando-se de uma visão idealizada do popular como universo atrasado e mergulhado no preconceito" (2008:57).

${ }^{24}$ Sobre a transformação de um "caso" em uma "causa", ou seja, da transformação de conflitos particulares em causas coletivas, Boltanski afirma que "no curso de um caso, a aposta principal da disputa em que se encontram envolvidos os diferentes protagonistas é precisamente o seu caráter individual ou coletivo, singular ou geral. [...] Segundo a configuração do caso, certos atores se empenham em 'desinflá-lo' para mostrar que este foi 'completamente montado' para 'reduzi-lo a suas justas proporções', enquanto outros, ao contrário, se apressam em todos os sentidos a revelar o seu 'verdadeiro rosto', a mostrar suas 'facetas ocultas' e fazer ver, com isso, que o caso concerne, 'na realidade', a bastante mais gente do que pudéramos imaginar à primeira vista: concerne a 'todo o mundo'. É a esse preço que ele é transformado em uma causa coletiva" (2000:25). No caso da luta clandestina, os militantes eram levados a ocultar a faceta coletiva de sua causa, revelando seu "verdadeiro rosto" nas ações espetaculares ou nas rupturas definicionais de situações. Em sentido inverso das situações analisadas por Boltanski, os militantes pagavam, paradoxalmente, com o isolamento social a vontade de projetar adiante, em segurança, sua causa coletiva.

${ }^{25}$ Referindo-se à noção de resistência como uma ruptura pela afirmação da força de dizer não, Jacques Semelin (2011:30) sustenta que "passar da dissidência à resistência é tentar fazer com que sua recusa seja compartilhada; quer dizer convencer e organizar. A resistência supõe uma 'démarche' de comunicação, tanto interna como externa. Para resistir, é preciso construir modos clandestinos de ligação, tocar a opinião para ampliar sua audiência".

${ }^{26}$ Convém destacar que cada cena dramatúrgica, para os clandestinos, não representava apenas um elemento-quadro de sua performance, mas também uma condição internalizada por eles próprios, à medida que podiam controlar reflexivamente seus papéis nas situações de interação de que participavam. 
${ }^{27}$ Este interstício tenso, situado entre os espaços privados e públicos nas condições da luta clandestina, sugere a latência daquilo que Teixeira Lopes chamou de espaços públicos periféricos, aqueles que "tendem a escapar às fachadas e à visibilidade, fluindo na vida cotidiana como lugares intersticiais, negociados e experimentados muitas vezes de forma agonística, imbricados na estruturação de novas subjetividades e encontros, radicados no princípio da não indiferença à diferença" (J. Teixeira Lopes apud R. Proença Leite 2008:131). Analogamente, a respeito de espaços públicos especificamente literários para a circulação de "textos ocultos", Kathy V. Dinh sublinha que "o texto oculto necessita também de um público, mesmo que o dominante não faça parte deste público. Era importante para os resistentes criar uma esfera social, uma comunidade de leitores separada do controle e da vigilância hegemônica para produzirem seus discursos de resistência" (2011:110-121; trad. minha).

${ }^{28}$ Para Ridenti (1993:248), "esgotaram-se os movimentos sociais de 1967 e 68, quer pela repressão policial generalizada; quer pela recuperação econômica com o 'milagre brasileiro'; quer pela manipulação ideológica destes e de outros fatores pelo regime civil-militar; quer pela atuação política dos movimentos sociais e das próprias esquerdas em geral e, em particular, das armadas". Segundo Oliveira (1987:133 apud Ridenti 1993:194), "devido ao boom da economia brasileira após 1969, o regime civilmilitar pôde obter êxito provisório no atender, ainda que desigualmente, os interesses contraditórios do capital e do trabalho [...]". Chauí (1987:81 apud Ridenti 1993:195), por sua vez, assinala que "quando a força do adversário é vista como onipotente [...] não só é preciso que os fracos estejam 'todos unidos', mas também que seu anseio de mudança não seja causa de carnificina e destruição".

\section{Referências bibliográficas}

ABRAMO, Zilah \& MAUÉS, Flamarion (orgs.). 2006. Pela democracia, contra o arbítrio: a oposição democrática, do golpe de 1964 à campanha das Diretas Já. São Paulo: Editora Fundação Perseu Abramo.

ALBUQUERQUE, José Augusto G. (coord.). 1977. Classes médias e política no Brasil. Rio de Janeiro: Paz e Terra.

ALMEIDA, Maria Hermínia T. de \& WEIS, Luís. 1998. "Carro zero e pau-de-arara: o cotidiano da oposição de classe média ao regime militar". In: Lilia Moritz Schwarcz (org.), História da vida privada no Brasil: contrastes da intimidade contemporânea. Vol. 4. São Paulo: Cia. das Letras. pp. 319-409.

BARTHES, Roland. 2002. Comment vivre ensemble - simmulations romanesques de quelques espaces quotidiensNotes de cours et séminaires au Collège de France (1976-1977), Traces écrites. Paris: Ed. Seuil /Imec (Texto estabelecido por Claude Coste).

BASTOS, Natalia de Souza. 2004. Mulheres em armas: memória da militância feminina contra o regime militar brasileiro. Monografia. Universidade 
Federal do Rio de Janeiro - UFRJ, Instituto de Filosofia e Ciências Sociais IFCS, Departamento de História.

BENJAMIN, Walter. 2006. Passagens. Belo Horizonte/São Paulo: EdUFMG/Imprensa Oficial.

BERTOLINO, Osvaldo. 2006. "A perda de uma guerreira: morre Marilda Costa Danielli", Diário Vermelho, 24/03/2006.

BETTO, Frei. 2000. Batismo de sangue. A luta clandestina contra a ditadura militar. 11 a . ed. São Paulo: Editora Casa Amarela Ltda.

BOLTANSKI, Luc. 2000. El amor y la justicia como competencias - tres ensayos de sociologia de la acción. Buenos Aires: Amorrotu Editores.

CALDAS, Álvaro. 2004. Tirando o capuz. $5^{\mathrm{a}}$. ed. Rio de Janeiro: Garamond.

CÁRCAMO, Juan Garcia. 1993. "Microsociologia e historia de lo cotidiano", Ayer, 19:189-222.

CATELA, Ludmila S. 2001. Situação-limite e memória - A reconstrução do mundo dos familiares de desaparecidos da Argentina. São Paulo: Hucitec-Anpocs. COMPANS, Rose. 2010. Habitação social e legitimação política no subúrbio carioca. Projeto Clandestinidade e Cidade, IPPUR/UFRJ, Rio de Janeiro. Mimeo, 35pp.

CEFAÏ, Daniel. 2003. "Qu' est-ce que c'est une arène publique? Quelques pistes pour une approche pragmatique". In: D. Cefai \& I. Joseph (orgs.), Heritage du pragmatisme - conflits d'urbanité et épreuves de civisme. Paris: La Tour d'Aigues, Editions de l'Aube. pp. 51-82.

CRANG, Mike \& TAVLOU, Penny S. 2001. "The ciy and topologies of memory". Environment and Planning D: Society and Space, 19:161-177.

DANIEL, Herbert. 1982. Passagem para o próximo sonho. Rio de Janeiro: CODECRI.
DE LANDA, Manuel. 2006. A new philosophy of society - assemblage theory and social complexity. London/ New York: Continuum.

DE LUCA, Derlei Catarina. 2002. No corpo e na alma. Criciúma: Ed. do autor.

DE SARDAN, Jean-Pierre O. 1995. “La politique de terrain - sur la production des donnés en anthropologie". Enquête, 1:71-109.

DIAS, Ângela Maria. 2005. “Nelson Rodrigues e o Rio de Janeiro: memórias de um passional". Alea: Estudos Neolatinos, 7(1). Disponívelem: http://www.scielo.br/scielo. php? script $=$ sci_arttext $\&$ pid $=$ S1517 106X2005000100007. Acesso em: $21 / 04 / 2012$.

DINH, Kathy V. 2011. "La littérature francovietnamienne: une réponse au colonialisme". Voix plurielles, 8(1):110-121.

FACINA, Adriana. 2004. Santos e canalhasuma análise antropológica da obra de Nelson Rodrigues. Rio de Janeiro: Ed. Civilização Brasileira.

FALCON, Yara. 2007. Mergulho no passado - a ditadura que vivi. Olinda: Ed. Livro Rápido.

FERNANDES Jr., Ottoni. 2004. O baú do guerrilheiro. Memórias da luta armada urbana no Brasil. Rio de Janeiro: Record.

FERREIRA, Elizabeth F. Xavier. 1996. Mulheres, militância e memória. Rio de Janeiro: Fundação Getúlio Vargas.

FREHSE, Fraya. 2008. "Erwin Goffman sociólogo do espaço". Revista Brasileira de Ciências Sociais, 23(68):155-166

FRÚGOLI Jr., Hector. 2007. Sociabilidade urbana. Rio de Janeiro: Zahar.

GABEIRA, Fernando. 1988. O que é isso companheiro? Rio de Janeiro: Guanabara.

GOFFMAN, Erving.1974. Les rites d'interaction. Paris: Les Éditions de Minuit. - 2008. A representação do eu na vida cotidiana. 15a. ed. Petrópolis: Ed. Vozes. 
. 1993. "La communication en défaut". Actes de la Recherche en Sciences Sociales, 100:66-72.

HIRSCHMAN, Albert O. 1996. Autossubversão. São Paulo: Cia das Letras.

JOSEPH, Isaac. 2000. Erwin Goffman e a microssociologia. Rio de Janeiro: Ed. FGV.

KEHL, Maria Rita. 2005a. "Um só povo, uma só cabeça, uma só nação". In: Adauto Novaes (org.), Anos 70-ainda sob a tempestade. Rio de Janeiro: Ed. Aeroplano/ SENAC-Rio. pp. 405-424. . 2005b. "As novelas, novelinhas e novelões: mil e uma noites para as multidões". In: Adauto Novaes (org.), Anos 70 ainda sob a tempestade. Rio de Janeiro: Ed. Aeroplano/ SENAC-Rio. pp. 425-443. KOSELLECK, Reinhart. 2006. Futuro passado. Rio de Janeiro: Contraponto.

LEPAPE, Pierre. 1998. "La nostalgie du nomadisme". Resenha do livro de JeanDidier Urbain, Secrets de voyage menteurs, imposteurs et autres voyageurs invisibles. Paris: Payot. Le Monde des Livres, p. II, 22/05/1998.

LIMA, Haroldo; ARANTES, Aldo. 1984. História da Ação Popular - da JUC ao PC do B. São Paulo: Editora AlfaÔmega.

LINHART, Virginie. 1994. Volontaires pour l'usine - vies d'établis 1967-1977. Paris: Seuil.

MAGALHÃES, Vera Silvia. 2005. "Micropolítica do afeto". Global, 5:23-27.

MORIN Edgar. 2000. "Dos demônios - atelier ao vivo do pensamento de Edgar Morin". Sesc Vila Mariana, São Paulo. Disponível em: http://edgarmorin. sescsp.org.br/arquivo/download/arquivos/atelier_p2.pdf. Acesso em: 01/2012.

NEVEU, Erik. 2008. "Rétablir les établis". Savoir/agir, 6:49-58.

PARK, Robert Ezra. 1976. "A cidade: sugestões para a investigação do com- portamento humano no meio urbano". In: O. G. Velho (org.), O fenômeno urbano. $3^{\mathrm{a}}$. ed. Rio de Janeiro: Zahar. pp. 26-67.

POLLAK, Michel. 1989. “Memória, esquecimento, silêncio". Estudos Históricos, 2(3):3-15.

PROENÇA LEITE, R. (org.). 2008. Cultura e vida urbana - ensaios sobre a cidade. São Cristóvão: Editora UFS.

REIS FILHO, Daniel A. 1989. A Revolução faltou ao encontro. São Paulo: Brasiliense.

RIDENTI, Marcelo. 1993. O fantasma da revolução brasileira. São Paulo: Ed. UNESP.

SAID, Edward. 2003. Reflexões sobre o exílio. São Paulo: Companhia das Letras.

SCOTT. James C. 2004. Los dominados y el arte de la resistencia. Cidade do México: Ediciones Era.

SEMELIN, Jacques. 2011. Face au totalitarisme - la résistance civile. Paris: André Versaille Editeur.

SIMMEL, Georg. 2003 [1996]. Secret et sociétés secrètes. Belval: Circé/ Poche.

TEIXEIRA, Carla Costa. 1998. Resenha do livro de Elizabeth F. Xavier Ferreira, Mulheres, militância e memória. Rio de Janeiro: Fundação Getúlio Vargas Editora. Mana. Estudos de Antropologia Social, 4(2):146-149.

VIÑAR, Maren \& VIÑAR, Marcelo. 1992. Exílio e tortura. São Paulo: Escuta.

WALDMAN, Berta. 1997. "O império das paixões: uma leitura dos romancesfolhetins de Nelson Rodrigues". Cadernos PAGU, 8(9):159-176.

WISNIK, José Miguel. 2005. "O minuto e o milênio ou 'Por favor, professor, uma década de cada vez'". In: Adauto Novaes (org.), Anos 70 - ainda sob a tempestade. Rio de Janeiro: Ed. Aeroplano/ SENAC-Rio. pp. 25-33. 


\section{Resumo}

Durante o regime ditatorial que se seguiu ao golpe de 1964 no Brasil, as ações de resistência desenvolveram-se basicamente nas cidades. Nos testemunhos de antigos militantes, a clandestinidade política é correntemente associada a metáforas do "exílio dentro da cidade", experiências de isolamento social. Mas na sociabilidade dos clandestinos, a despeito do forte contexto repressivo, não se teria verificado também alguma forma de "vida pública"? A presente pesquisa, realizada a partir de entrevistas com 50 ex-militantes, propõese a discutir tal questão. As narrativas reunidas denotam que, a despeito do movimento permanente de destruição de arenas públicas que configurou o autoritarismo, os comportamentos adaptativos por parte dos clandestinos e dos indivíduos que com eles interagiam resultaram na frequente constituição de "consensos operacionais" na definição de situações de interação, consensos estes pautados na gestão das distâncias tanto políticas como culturais.

Palavras-chave Clandestinidade, Ditadura, Microssociologia, Cidade, Militantismo.

\section{Abstract}

During the dictorial regime that followed the 1964 military coup in Brazil, resistence actions basically developed in the cities. In the testimony of the old activists of the time, clandestine politics are correctly associated with metaphors of "an exile within the city", and feelings of social isolation. But in spite of the strong repressive context, can we not see in militant sociability some form of "public life"? The present research, based upon interviews with 50 ex-militants, proposes to discuss this question. The narratives that we have brought together here show that in spite of the permanent movement of destruction of the public arenas by authoritatianism, the adaptive behaviors of underground militants and the people who interacted with them resulted in the frequent constitution of "operational consensuses" regarding interactive situations. These consensuses were based upon the adroit management of both political and cultural distance.

Key words Clandestine, Dictatorship, Micro-sociology, City, Activism. 
No volume 18 n. 1, pp. 7-35, artigo Entre a lua e a rua: uma topologia social da clandestinidade política na cidade do Rio de Janeiro, 1969-1973, de Henri Acselrad, foi feita a seguinte alteração:

- Introdução da seguinte nota de fim após o título do artigo: “O presente texto resulta do projeto de pesquisa 'Clandestinidade e cidade', apoiado pela Faperj e realizado com a participação das pesquisadoras Gilberta Acselrad e Iara Ferraz”. 